\title{
E-Marketing of Village Tourism Development Strategy (Case Study in the Tourist Village Puncak Sosok)
}

\author{
Ramadhani ${ }^{1}$, Suswanta ${ }^{2}$, Syahrial Shaddiq ${ }^{3}$ \\ 1,2 Universitas Muhammadiyah Yogyakarta (UMY), Yogyakarta, Indonesia \\ ${ }^{3}$ Graduate Programme, Universitas Islam Indonesia (UII), Yogyakarta, Indonesia \\ E-mail: ${ }^{1}$ ramadhanii150199@gmail.com, ${ }^{2}$ soes_umy@yahoo.com \\ ${ }^{3} 17931001 @$ students.uii.ac.id
}

\begin{abstract}
Attractions peak figure is one of the national tourism objects located in the village Bawuran, District Pleret, Bantul which have tourism potential is extraordinary for the future. The purpose of this study is to describe the strategy of the development of the tourism village of Puncak Sosok. The approach used in this research is descriptive qualitative data collection methods such as interviews with informants interested and involved in the direct management attractions peak figure. Analysis of data obtained through data collection, data verification, data presentation, and conclusion. The results showed that the peak tourism village development strategy figure through the potential of natural resources, marketing strategy, and human resource management is already well underway with a high enough public participation in all stages of management. Therefore, electronic marketing (e-marketing) is the right tourism development strategy in Puncak Sosok.
\end{abstract}

Keywords-Rural Tourism, Tourism Village Development, Strategy Development.

\section{INTRODUCTION}

The development of the tourism sector aimed to improve rural economic growth, reduce poverty, increase welfare and is expected to reduce poverty. The presence of an end to the purpose of tourism is closely linked to the importance of the role and participation of the community and the village government. The role of the whole element can be implemented in various forms of rural tourism development [1].

According to the tourism sector is currently occupying the second position as the largest industry after oil and gas, it is not possible through this sector makes a very promising foreign exchange earner [1]. Moving on from that the government should further prioritise programs with the establishment of village-based tourism. Also, to make this program as an alternative approach to development in various regions [2].

Bantul district which already known to have the potential attractiveness objects and tourism (ODTW) either villagebased nature tourism and cultural tourism is very diverse very necessary marketed effectively. The marketing strategy which aims to increase tourist attraction, easy access to travel information, conduct outreach programmes, promote to other regions, the speed and convenience of service is a requirement of a marketing strategy. Today almost every area has a village-based ODTW that seeks to develop the potential of the village to bring in tourists both local and foreign tourism [2].

Proof of the development process is deemed effective at the attraction by obtaining the peak figure for the sake of awards received awards Attractions peak figure in the still fairly young age. First on the Moon in October 2019 took part in the Race of Youth pioneer levels of Bantul and Attractions peak figure won 1 , and represent the district at the provincial level back in 1st place, and the latter representing the province at the national level as the winner three young pioneers in the field of natural resources and tourism (from Kemenpora). A week after following the archipelago Travel Competition, Ministry of underdeveloped villages and transmigration (nominated for 10 large, advanced category) amended version [3].

The impact of these conditions was led to competition between regions, each wanting Attraction favors its region. That's why every area on the stimulus to develop the potential of innovative village-based tourism. Moving on from the above background has given rise to research "how rural tourism development strategy of the peak figure?" [4].

The research objective to be achieved from this study: 1 . Knowing the rural tourism development strategy and the peak figure, 2. Knowing the constraints on the implementation of the strategy to know the solution. The benefits that you want to get the authors of this study are: 1 . The hope becomes the input for the local government of Bantul Regency, especially in the development of potential tourist attraction and the village-based rural tourism, 2. Provide information for the benefit of businesses and tourism services [5].

\section{LITERATURE REVIEW}

\section{a. Development Strategy}

The reference [2] said the development of the product is determined by all relevant stakeholders and implemented in an integrated manner. In carrying out the development of 
rural tourism, it is necessary the appropriate starting planning in determining the proposed programme or activity up to the Travel Awareness Group (Pokdarwis) in order to raise the skills and knowledge of the community through a programme to be executed. Rural tourism development is greatly influenced by some sectors such as institutional, objects and attractions, as well as facilities attraction [3].

In another study says management can be implemented if the tourist village of tourism resources, marketing, human resource management, and conflict management has been able to be managed together with the participation of people who are aware tours [4]. [5] describes the forms of public participation that can be a thought for expressing ideas, physical force participation, participation skills, and competency skills. Subsequently [6] rural development strategy could travel through programmes with efforts to develop and increase the competitiveness of products and the tourism industry, the market share of enhancing tourism through promotional activities, increased cooperation MultiStakeholders, In another study about the impact of rural tourism development a positive impact on the economic development of rural communities of which can improve people's incomes, increase business opportunities, enhance community ownership in and control, and increase government revenue through travel levy [7].

\section{b. Tourism Village}

In [8] that Tourism is a service or a service. Consumers will enjoy these products to gain experience of traveling he does. Its nature is intangibility, heterogeneity, perishability, inseparability. This explanation is reinforced by [9] tourist village is an area or region in which there are many tourist attractions (cultural, artificial, natural) that are packaged in ways that tourists visiting the dance [10].

In a previous study [11] explained that rural tourism is a way to enjoy the attractions, accommodation and tourism facilities in a society still upholds the tradition. Thus, the primary focus of a tourist village is the native tradition that still fused with community life, so that rural tourism cannot be separated from tradition [12]. With regard, individual capacity understanding knowledge and tourist village concept will influence the attitude of tourism stakeholders in managing the tourist village [13]. Later knowledge about the concept of rural tourism will usher tour players to use the concept of tourism or not [14]. On the other hand, other studies that correlate with this study are as follows [15-37].

\section{c. Theoretical Framework}

In [13] describes the detailed SWOT analysis as an advanced aspect of strength $(\mathrm{S})$, weakness $(\mathrm{W})$, opportunity (O) and threat $(\mathrm{T})$.

Components in marketing by [14] divided marketing into four parts, namely:

1. Product

The products are the real deals in the market, brand, and presentation.

2. Price

Price is the amount of money that must be paid customers for the product, where the price should be adjusted to the customer's view that consumers do not switch to competitors the

3. Place

It is the company's activities to make the product affordable and available to the target market.

4. Promotion

Promotion is the company's activities to communicate its products.

\section{RESEARCH METHODS}

\section{a. Scope}

Limits the scope of the study authors in this study is to include restrictions in terms of location and problems. In terms of location, the scope of research is located in the village of Bawuran, Pleret subdistrict, Bantul Yogyakarta. As for the scope of the issues that the author adopted is "rural tourism development strategy, case studies attraction peak figure". The development strategy which is intended reference to the SWOT analysis theory and the theory of marketing (product, price, place, and promotion)

\section{b. Data Collection Technique}

In gathering the required data, researchers used three techniques among them in-depth interview to the village and the chairman (Pokdarwis) where the informant felt the depth of information that would be studied, in this case, the depth of information on the strategy development of rural tourism case studies peak figure of which is located in Bawuran village.

Observations in doing are reviewing the study site located in the village Bawuran. These observations were done by observing directly to the condition of the study site, the village, the perpetrators of tourism and tourism activities that took place at of Puncak Sosok, so that researchers get an idea of the object of research related

\section{c. Data Analysis Technique}

This research is qualitative, the data were analysed using a qualitative descriptive method. This method is done after the required data has been collected and arranged systematically and described using words so as to give a clear idea to the reader. The data obtained in the field of information, photos photographs and documents relating to the circumstances relating to the attraction and tourism development strategy.

\section{DISCUSSION}

\section{a. Research Sites}

The village is located in the district Bawuran Pleret Bantul Yogyakarta Special Province. Bawuran village situated on the east of the downtown district of Bantul. Distance Village Bawuran with Bantul district center approximately $20 \mathrm{~km}$. Village Location Bawuran $3 \mathrm{~km}$ to the east of the center of the District Pleret. Bawuran village is bordered by several villages including Wonolelo village, village Segoroyoso, Sitimulyo village, village and village Srimulyo Wukirsari. In administrative Village Bawuran limited by:

North : Sitimulyo village and Village Srimulyo 
East : Village Wonolelo

Southside : Saro Wukir Village and Village Segoroyoso

West Side : Village Pleret

\section{b. Strategy Development and Marketing}

i. Product

Attraction beginning of its presence in the village Bawuran peak figure itself began in 2017. Since 2008 the village government has begun to identify and observe the points in the region Desa Bawuran that is considered to have tourism potential. The highlight of the figure itself was originally gebang embryo at the top, with initial activities Bike Downhill event Kapolda cup to introduce the attraction at first. Then in the move, because gebang peak region which is about $500 \mathrm{~m}$ from the top of the figure today may not be developed because the status of the land is privately owned.

The products offered on the figure itself Attractions Peak is a peak tourist that offers the beauty of the natural charm by presenting landscape DIY from the summit. When daytime tourists are pampered with a view of the natural beauty around Bantul, Sleman, Jogja City, and parts of South Mountain. Overlay mountains like Mount Merapi, Merbabu, Sumbing also able to be enjoyed with a clear from these figures highlight attractions. When night tourism pampered with glitter DIY landscape scenery seemed to bring tourists were vacationing in the land above the clouds. With a live stage musical accompaniment provided by the tour manager while enjoying culinary sold in stalls owned by residents who have a fairly diverse menu and an affordable price.

Not only the natural beauty that can be enjoyed tourism when visiting attractions but still there is a peak figure of other facilities such as, Track bike downhill, Camping Ground, Wedding, Outbound (small scale).

\section{ii. Price}

The village government and does not burden the manager should attract visitors with a great levy, as in its management and in the age of attraction that is still fairly young, still lead management process to profit. when the later product the law was clear, had issued a permit and also consider the price to be offered to tourism to see the facilities that are already available and already in a sense worthy to be sold, so far, the manager not to burden visitors with retribution. Then it is also related to draw attention to competitiveness in order to create competitive prices and are able to compete and bring cheap tourist attraction. Revenue is also not solely depending on the levy which has been running for this.

\section{iii. Place}

Amenities attractions peak figure of researchers deemed complete enough, important aspects such as access roads to the summit, bags of parking, food, places of worship, public toilets, and also sports a somewhat unique take pictures end has been able to fulfill the manager Attractions peak figure. For facilities such as lodging or homestay temporarily Attractions of Puncak Sosok support not have such facilities. But for the time being, some residents participate voluntarily accommodate tourism their home when required to stay onsite Attractions peak figure.
Attractions of Puncak Sosok also open up when visitors and tourists want to hold any activity or event that implementation is located in the tourist attraction. The licensing process is very easy to make application activity submitted to the village headman and also a manager of attraction (Pokdarwis). As for the licensed activity of the manager Attractions peak figure like makrab activities, camping, downhill, and events of the new year.

\section{iv. Promotion}

A promotional strategy that has been implemented from the beginning of appearance attractions until now both the manager Attractions peak figure and also the village government Bawuran is by way of cooperating with communities that are at a great such as community bicycle, club car, model aircraft, community animals and nature lover's community. In collaboration with relevant stakeholders such as the Department of Tourism Bantul, print media and electronic media such as (newspapers, radio, and television). The latest strategy is promotion done by using social media as a platform, so far the media used is channel Youtube, Instagram, Facebook. All the steps that have been carried out are considered very effective for introducing Attractions figures highlight to the wider community.

\section{c. SWOT Analysis}

Strength

\begin{tabular}{|c|l|}
\hline No. & \multicolumn{1}{|c|}{ Information } \\
\hline 1. & $\begin{array}{l}\text { Puncak Sosok Bawuran in the village has a } \\
\text { unique appeal as a tourism village. }\end{array}$ \\
\hline 2. & $\begin{array}{l}\text { Puncak Sosok in the village Bawuran has } \\
\text { some interesting rides for tourists. }\end{array}$ \\
\hline 3. & $\begin{array}{l}\text { Puncak Sososk in the village Bawuran own } \\
\text { infrastructure is adequate complementary. }\end{array}$ \\
\hline 4. & $\begin{array}{l}\text { Access to the peak figure in the village is very } \\
\text { easy using either Bawuran } 2 \text { wheel/wheel } 4 .\end{array}$ \\
\hline 5. & $\begin{array}{l}\text { Puncak Sososk Bawuran in the village has a } \\
\text { very indulgent landscapes travelers. }\end{array}$ \\
\hline 6. & $\begin{array}{l}\text { Puncak Sosok in the village Bawuran installing } \\
\text { a very cheap price. }\end{array}$ \\
\hline 7. & Attitude people participated. \\
\hline 8. & Public disclosure of the visitors. \\
\hline 9. & $\begin{array}{l}\text { There is a community/community as tour } \\
\text { manager tourism awareness. }\end{array}$ \\
\hline
\end{tabular}

\section{Weakness}

\begin{tabular}{|c|l|}
\hline No. & \multicolumn{1}{c|}{ Information } \\
\hline 1. & $\begin{array}{l}\text { Many multitudes of rides that are not } \\
\text { attracted to tourists (unused). }\end{array}$ \\
\hline
\end{tabular}




\begin{tabular}{|c|l|}
\hline 2. & $\begin{array}{l}\text { Many multitudes of supporting facilities } \\
\text { unused (damaged / others). }\end{array}$ \\
\hline 3. & $\begin{array}{l}\text { service is not optimal from tourism } \\
\text { operators. }\end{array}$ \\
\hline 4. & $\begin{array}{l}\text { When it rains, and thereafter, the pungent } \\
\text { smell of the landfill Piyungan felt quite strong } \\
\text { and can impair the quality of tourism. }\end{array}$ \\
\hline
\end{tabular}

Opportunity
-Support full of
village
government
-The concept of
different
-Market good
travel
-Colab together
college

Opportunity
\begin{tabular}{|c|l|}
\hline No. & \multicolumn{1}{|c|}{ Information } \\
\hline 1. & $\begin{array}{l}\text { The existence of the government regulation } \\
\text { that encourages the development of tourism } \\
\text { in the village Bawuran }\end{array}$ \\
\hline 2. & $\begin{array}{l}\text { Concept vehicle which is different from the } \\
\text { other peaks in the area around Yogyakarta }\end{array}$ \\
\hline 3. & $\begin{array}{l}\text { Tourism market is still wide open, } \\
\text { especially in DIY }\end{array}$ \\
\hline 4. & $\begin{array}{l}\text { The concept of tourism development in } \\
\text { collaboration with Education Institutions / } \\
\text { Universities }\end{array}$ \\
\hline
\end{tabular}

Threat
\begin{tabular}{|c|l|}
\hline No. & \multicolumn{1}{|c|}{ Information } \\
\hline 1. & $\begin{array}{l}\text { People's economic condition is still very } \\
\text { dependent on the availability of natural } \\
\text { resources (objects), so prone to making tourism } \\
\text { asset for the fulfillment of life. }\end{array}$ \\
\hline 2. & $\begin{array}{l}\text { When not always innovate is not likely to be } \\
\text { replaced by new attractions springing another. }\end{array}$ \\
\hline 3 & Lack of coordination between SKPD. \\
\hline 4 & $\begin{array}{l}\text { Lack of coordination between the government } \\
\text { with the community. }\end{array}$ \\
\hline
\end{tabular}

$\begin{array}{lll} & \text { Strength } & \text { Weakness } \\ \text {-Natural beauty } & \text { Yet optimal } \\ \text { Cheap - } & \text { service' } \\ \text { Restribusi } & \text {-Facilities } \\ \text {-Access easy } & \text { unused } \\ \text { travel } & \text {-Wahana less } \\ \text { good-Facilities } & \text { desirable } \\ & \text { The smell of the } \\ & \text { landfill } \\ & \text { Piyungan - } \\ & \text { Aroma time } \\ & \text { after the rain. } \\ & \end{array}$

\section{Threat \\ -Dependency \\ community \\ Other travel - \\ objek more \\ innovative}

Strength-
Opportunity
Attraction very
good chance in
the future with
the support of
all elements of
the village
community and
local
government.

\section{Strength-}

Threat

Community empowerment

is a priority so that all elements of society to participate in the

management of attractions to remind innovative services travelers
WeaknessOpportunity Innovation that can increase the attraction of tourists to visit tourist attractions.

Weakness-

Threat

Maximising existing natural resources as well as local human resources to participate and contribute, good energy, thoughts, and expertise in to managing the process of attraction.

\section{CONCLUSION}

Attractions development strategy, cannot be separated from the peak figure of public awareness of the tourism potential of their respective regions. The village government took steps to maximise the potential of rural youth village operates effectively and deliver results for the village to be even better. Attractions peak figure originated from the youth movement village with seriousness and solidarity with the residents and also contribute from the village government to encourage the development of potential. But all is not without obstacles, human resources are still a PR man to continue the development of rural tourism to become better. Proof of it is considered an effective development process is by obtaining the sake of awards received awards attractions peak figure in the still fairly young age.

From the achievements the past 2 years to become champions three young pioneer national level, ranking 10 tours of the archipelago national, expectations of stakeholders are central we hope there is a kind of programme and also special attention to of Puncak Sosok so that the peak tourist figure not only as it is now. A business hoping no derivative products that could be developed in cooperation with all elements of the rural community to progress Bawuran peak figure in the years to come. With this award may be a lighter motivation other colleagues, can bring ideas and innovations with the aim to produce products that can support the existence of attraction. 


\section{REFERENCES}

[1] Pitana, I. G., \& Gayatri, P. G. (2005). Sosiologi Pariwisata: Kajian sosiologis terhadap struktur, sistem, dan dampak-dampak pariwisata. Andi.

[2] Purnomo, C. (2008). Efektifitas Strategi Pemasaran Produk Wisata Minat Khusus Gua Cerme, Imogiri, Bantul. Jurnal Siasat Bisnis, 12(3).

[3] Kartika, A. (2015). Tourism Village Development For Community-Based Ecotourism Embodiment (Community-Based Ecotourism) In Stone Town. Journal of Public Administration, 3 (4), 670-675.

[4] Prabowo, SE, Hamid, D., \& Prasetya, A. (2016). Analysis of public participation in the development of rural tourism (study at the Village Pujonkidul Pujon Malang). Journal of Business Administration, 33 (2), 18-24.

[5] Martiarini, R. (2017). Tourism Village Development Strategy for Rural Community Empowerment Through Ketenger Baturraden.

[6] Winasis, A., \& Setyawan, D. (2016). The effectiveness of the programme through the institutional development of rural tourism in the improvement of natural resources (SDA). JISIP: Journal of Social and Political Sciences, 5 (2).

[7] Sidiq, AJ, \& Resnawaty, R. (2017). Rural tourism development based on local community participation in the tourist village Linggarjati Kuningan, West Java. Proceedings of Research and Community Service, 4 (1), 38-44.

[8] Purmada, DK, \& Judge, L. (2016). Tourism Village management in the Perspective of Community Based Tourism (Case Study on Gubugklakah Tourism Village, District Poncokusumo, Malang). Journal of Business Administration, 32 (2), 15-22.

[9] Wijayanti, A. (2017). Analysis of Impact of Tourism Village Development on the Economy Kembang Arum Local Communities. Bachelor Wiyata Tamansiswa Yogyakarta.

[10] Nalayani, NNAH (2016). Evaluation and Development Strategy Tourism Village in Badung regency, Bali. Journals Master of Tourism (SEE).

[11] Hermawan, H. (2016). Nglanggeran Tourism Village development impact on the economy of local communities. Tourism Journal, 3 (2), 105-117.

[12] Astuti, NNS (2017). Strategy development potential ingesta village as a tourist village-based ecotourism. SOSHUM: Journal of Social and Humanities [Journal of Social Sciences and Humanities], 6 (1), 113.

[13] Andayani, AAI, Martono, E., \& Muhammad, M. (2017). Community Empowerment Rural Development Through Tourism and Cultural Implication to Social Security Area (Study In Penglipuran Bali Tourism Village). National Security Journal, 23 (1), 1-16.

[14] Ulfah, IF, Setiawan, A., \& Rahmawati, A. (2017). Rural Development Agro-Based Local Potential in the village Bumiaji, Batu, East Java. Politics Indonesia: Indonesian Political Science Review, 2 (1), 46-64.

[15] Kalyanam, K., \& McIntyre, S. (2002). The e-marketing mix: a contribution of the e-tailing wars. Journal of the academy of marketing science, 30(4), 487-499.
[16] Singh, N., Krishnamurthy, S., Sheth, J. N., \& Sharma, A. (2005). International e-marketing: opportunities and issues. International Marketing Review.

[17] Chang, H. H., Wang, Y. H., \& Yang, W. Y. (2009). The impact of e-service quality, customer satisfaction and loyalty on e-marketing: Moderating effect of perceived value. Total Quality Management, 20(4), 423-443.

[18] Gilmore, A., Gallagher, D., \& Henry, S. (2007). Emarketing and SMEs: operational lessons for the future. European Business Review.

[19] Coviello, N. E., Brodie, R. J., Brookes, R. W., \& Palmer, R. A. (2003). Assessing the role of e-marketing in contemporary marketing practice. Journal of Marketing Management, 19(7-8), 857-881.

[20] El-Gohary, H. (2010). E-Marketing-A literature Review from a Small Businesses perspective. International journal of business and social science, 1(1).

[21] Trainor, K. J., Rapp, A., Beitelspacher, L. S., \& Schillewaert, N. (2011). Integrating information technology and marketing: An examination of the drivers and outcomes of e-Marketing capability. Industrial marketing management,40(1), 162-174.

[22] Dann, S., \& Dann, S. (2011). E-marketing: theory and application. Macmillan International Higher Education.

[23] Eid, R., \& El-Gohary, H. (2013). The impact of Emarketing use on small business enterprises' marketing success. The Service Industries Journal, 33(1), 31-50.

[24] Dominici, G. (2009). From marketing mix to emarketing mix: a literature overview and classification. International journal of business and management, 4(9), 17-24.

[25] Dennis, C., \& Harris, L. (2002). Marketing the eBusiness. Routledge.

[26] El-Gohary, H. (2012). Factors affecting E-Marketing adoption and implementation in tourism firms: An empirical investigation of Egyptian small tourism organisations. Tourism management, 33(5), 1256-1269.

[27] Varey, R. J. (2002). Relationship marketing: dialogue and networks in the e-commerce era. Chichester: Wiley.

[28] Krishnamurthy, S. (2006). Introducing E-Markplan: A practical methodology to plan e-marketing activities. Business Horizons, 49(1), 51-60.

[29] Rahimnia, F., \& Hassanzadeh, J. F. (2013). The impact of website content dimension and e-trust on e-marketing effectiveness: The case of Iranian commercial saffron corporations. Information \& Management, 50(5), 240247.

[30] Salehi, M., Mirzaei, H., Aghaei, M., \& Abyari, M. (2012). Dissimilarity of E-marketing VS traditional marketing. International journal of academic research in business and social sciences, 2(1), 510.

[31] Brodie, R. J., Winklhofer, H., Coviello, N. E., \& Johnston, W. J. (2007). Is e-marketing coming of age? An examination of the penetration of e-marketing and firm performance. Journal of interactive marketing, 21(1), 2-21.

[32] Brodie, R. J., Winklhofer, H., Coviello, N. E., \& Johnston, W. J. (2007). Is e-marketing coming of age? An examination of the penetration of e-marketing and 
firm performance. Journal of interactive marketing, 21(1), 2-21.

[33] Kalyanam, K., \& McIntyre, S. (2002). The e-marketing mix: a contribution of the e-tailing wars. Journal of the academy of marketing science, 30(4), 487-499.

[34] N. Sheth, J., \& Sharma, A. (2005). International emarketing: opportunities and issues. International Marketing Review, 22(6), 611-622.

[35] Chang, H. H., Wang, Y. H., \& Yang, W. Y. (2009). The impact of e-service quality, customer satisfaction and loyalty on e-marketing: Moderating effect of perceived value. Total quality management, 20(4), 423-443.

[36] El-Gohary, H. (2010). E-Marketing-A literature Review from a Small Businesses perspective. International journal of business and social science, 1(1).

[37] Coviello, N. E., Brodie, R. J., Brookes, R. W., \& Palmer, R. A. (2003). Assessing the role of e- marketing in contemporary marketing practice. Journal of Marketing Management, 19(7-8), 857-881. 